\title{
Expression of three diadinoxanthin de-epoxidase genes of Phaeodacylum tricornutum in Escherichia coli Origami $b$ and BL21 strain*
}

\author{
Monika Bojko1凶, Monika Olchawa-Pajor1, Urszula Tuleja1, Paulina Kuczyńska', Wojciech \\ Strzałka², Dariusz Latowski ${ }^{1}$ and Kazimierz Strzałka
}

In the diadinoxanthin cycle the epoxy group is removed from diadinoxanthin and diatoxanthin is created. This conversion takes place e.g. in diatoms with the involvement of the enzyme diadinoxanthin de-epoxidase. In one of the diatom species, Phaeodactylum tricornutum (CCAP 1055/1 strain with genome sequenced) three deepoxidase genes (PtVDE, PtVDL1, PtVDL2) have been identified, but only one of them (PtVDE) corresponds to violaxanthin de-epoxidase, an enzyme which is commonly found in higher plants. In these studies, the expression of two de-epoxidase genes of another Phaeodactylum tricornutum strain (UTEX 646), which is commonly used in diatom studies, were obtained in Origami $b$ and BL21 E. coli strains. The molecular masses of the mature proteins are about $49 \mathrm{kDa}$ and $60 \mathrm{kDa}$, respectively, for VDE and VDL2. Both enzymes are active with violaxanthin as a substrate.

Key words: diadinoxanthin cycle, marine diatoms, violaxanthin, deepoxidation

Received: 30 October, revised: 06 December, 2013; accepted: 19 December, 2013; available on-line: 30 December, 2013

\section{INTRODUCTION}

All photosynthetic organisms have developed photoprotective mechanisms with carotenoids playing a fundamental role in the dissipation of excess light energy. Photoprotection is connected with the de-epoxidased forms of xanthophyll pigments, which are formed by the enzymatic removal of epoxy groups under high light conditions. These reactions occur in those processes commonly known as xanthophyll cycles Jahns et al., 2009). Two of the most common among them are the violaxanthin and diadinoxanthin cycles. In the violaxanthin cycle, violaxanthin is de-epoxidased to zeaxanthin via antheraxanthin by the enzyme called violaxanthin deepoxidase (VDE), whereas in the diadinoxanthin cycle the epoxy group is removed from diadinoxanthin and diatoxanthin is created. Such conversion takes place e.g. in diatoms and is catalyzed by the enzyme diadinoxanthin de-epoxidase. In the past, in diatoms only one de-epoxidase enzyme, known as DDE, was postulated (Goss \& Jacob, 2010). Nowadays three genes of this enzyme have been identified in one of the diatoms, the Phaeodactylum tricornutum CCAP 1055/1 strain with genome sequenced (Siaut et al., 2007). However, only one of them is similar to VDE of the violaxanthin cycle. This gene is marked as PtVDE. The product of this gene is called VDE, and may be involved in the conventional xantophyll cycle. Two others genes of Phaeodactylum tricornutum de-epoxidase are referred to as VDE-like de-epoxidases (designated as PtVDL1 and PtVDL2, respectively), and are thought to be more specialized in the chromist-specific diadinoxanthin cycle (Coesel et al., 2008).

The purpose of our research was to obtain PADE, PAVDL1 and PAVDL2 genes of Phaeodactylum tricornutum (UTEX 646 strain), and their expression with the goal to obtain active enzymes with polyhistidine tag.

\section{METHODS}

Phaeodactylum tricornutum growth conditions. The Ph. tricornutum UTEX 645 strain was obtained from the Institute of Botany at Leipzig University. The culture was grown in an f/2 medium (Guillard \& Ryther, 1962; Guillard, 1975) made with 1.6\% sea salt (Tropic Marin), supplemented with $\mathrm{f} / 2$ vitamins (filter sterilized and added after autoclaving). Approximately $70 \mathrm{ml}$ of inoculum with optical density $\mathrm{OD}_{600} 0.3-0.4$ was used at the start of a $250 \mathrm{ml}$ batch culture. The cultures were grown at $15^{\circ} \mathrm{C}$ under white light at approximately $40 \mu \mathrm{mol} \mathrm{m} \mathrm{m}^{-2} \mathrm{~s}^{-1}$ in a $10 / 14 \mathrm{~h}$ photoperiod. The cultures were shaken several times a week during the light phase to keep cells in suspension and maintain an optimal exchange of gas and nutrients.

RNA purification and reverse transcription. Total RNA was prepared from a 5 day old $\mathrm{Ph}$. tricornutum batch culture, with OD $0.2-0.3$, using GeneJET Plant RNA Purification kit (Thermo SCIENTIFIC) according to manufacturer's instructions. Genomic DNA was removed from RNA by the incubation of $1 \mu \mathrm{g}$ RNA with DNaseI, RNase-free (Thermo SCIENTIFIC) at $37^{\circ} \mathrm{C}$ for $30 \mathrm{~min}$.

First-strand cDNA was synthesized using $1 \mu \mathrm{g}$ total RNA, M-Mul V Reverse transcriptase, Thermo Scientific

e-mail: M.Bojko@uj.edu.pl

*Presented at the 5th Central European Congress of Life Sciences "EUROBIOTECH 2013", Kraków, Poland.

Abbreviations: Asc, ascorbate; $\mathrm{Ax}$, anteraxanthin; $\mathrm{DDE}$, diadinoxanthin de-epoxidase, MGDG, monogalactosyldiacylglycerol; PCR, polimerase chain reaction; Pt, Phaeodactylum tricornutum; VDE, violaxanthin de-epoxidase gene; $V D L 1$, precursor of violaxanthin de-epoxidase like protein 1 gene; $V D L 2$, precursor of violaxanthin de-epoxidase like protein 2 gene; VDE, violaxanthin de-epoxidase; VDL1, precursor of violaxanthin de-epoxidase like protein 1; VDL2, precursor of violaxanthin de-epoxidase like protein $2 ; \mathrm{Vx}$, violaxanthin; $Z x$, zeaxanthin 
Table 1. List of primers used for PCR amplification of the de-epoxidase genes (BamHI and Ndel site underlined).

\begin{tabular}{|c|c|c|}
\hline $\begin{array}{l}\text { Name } \\
\text { of genes }\end{array}$ & Primer name & Sequences \\
\hline VDE & $\begin{array}{l}\text { VDEPhtriRevBamH281111 } \\
\text { VDEPhtriForNdel160511 }\end{array}$ & $\begin{array}{l}\text { 5'-CCGGATCCTTATTGCTGGGAGGTTCTC-3' } \\
\text { 5'-GAGCATATGAAGTTTCTCGGTGTTACCAG-3' }\end{array}$ \\
\hline VDL1 & $\begin{array}{l}\text { VDL1PhtriRevBamH281111 } \\
\text { VDL1PhtriForNdel160511 }\end{array}$ & $\begin{array}{l}\text { 5'-CCGGATCCTTAGCGTTCGCCTTGTATTC-3' } \\
\text { 5'-GAGCATATGCGATTCGCTTGGGTGGT-3' }\end{array}$ \\
\hline VDL2 & $\begin{array}{l}\text { VDL2Phtri RevBamH281111 } \\
\text { VDL2Phtri For Ndel160511 }\end{array}$ & $\begin{array}{l}\text { 5'-CCGGATCCTTAGTTCTTGACATCTTCTG-3' } \\
\text { 5'-GAGCATATGAAGCGAGCCACGAGGAA-3' }\end{array}$ \\
\hline
\end{tabular}

at 0 after 8 and $20 \mathrm{~h}$ and incubated with a urea lysis buffer $(8 \mathrm{M}$ urea, $20 \mathrm{mM}$ Tris, $9.0 \mathrm{pH}$ ) for $10 \mathrm{~min}$ at $100^{\circ} \mathrm{C}$. The presence of de-epoxidases was analyzed by gel electrophoresis (SDS-PAGE) stained with Coomassie Brillant Blue and transferred to PVDF membranes (pore size $0.45 \mu \mathrm{m}$, Immobilon-P) for western blotting. The membranes were then incubated for $16 \mathrm{~h}$ at $6^{\circ} \mathrm{C}$ with a mouse anti-His'Tag primary antibody (Sigma) followed by $1 \mathrm{~h}$

RiboLock RNase Inhibitor and Random primer (Fermentas) by incubation for $10 \mathrm{~min}$ at $25^{\circ} \mathrm{C}$ followed by $60 \mathrm{~min}$ at $37^{\circ} \mathrm{C}$. RNA and DNA concentration were determined spectrophotometrically at $260 \mathrm{~nm}$ (NanoDrop Litle Spectrophotometer, Thermo SCIENTIFIC).

PCR conditions. Primer pairs and $\mathrm{cDNA}$ were used as a template for the amplification of PtVDE, PtVDL1 and PtVDL2 (Pfu DNA Polymerase). The sense primer (Table 1) contained the initiation Met, $\mathrm{N}$ terminus codons of amino acid from the mature protein $(\mathrm{Ph}$. tricornutum CCAP 1055/1 strain) and NdeI site (underlined). The antisense primers (Table 1) contained the stop codon, $\mathrm{C}$ terminus codons of amino acid from the mature protein and BamHI site (underlined). PCR was performed using the following thermal condition: initial denaturation $95^{\circ} \mathrm{C}(3 \mathrm{~min})$, denaturation $95^{\circ} \mathrm{C}(30 \mathrm{~s})$, annealing $56^{\circ} \mathrm{C}(30 \mathrm{~s})$, extension $72^{\circ} \mathrm{C}(2 \mathrm{~min})$ carried out in 35 cycles and to a final extension of $72^{\circ} \mathrm{C}(15 \mathrm{~min})$ (S1000 Thermal Cycler, BioRad).

PCR single products of the expected size were confirmed by $1 \%$ agarose gel electrophoresis visualized by ethidium bromide staining.

Construction of plasmids and recombinant expression of de-epoxidases. PCR products were purified using the Ez-10 Spin column DNA Gel extraction Kit (Lab Empire)

PtVDE, PtVDL1 and PtVDL2 were digested by NdeI (by night) and BamHI (2 h) at room temperature (Fermentas), and inserted to dephosphorylated (Shrimp Alcaline Phosphatase, Fermentas) digested by NdeI (by night) and BamHI (2 h) (Fermentas) - pET-15b vector (Novagen), using a ligation kit (T4 DNA Ligase Fermentas). Plasmids were named pET-15b/PtVDE, pET-15b/ PtVDL1 and pET-15b/PtVDL2, respectively.

The sequences of PtVDE, PtVDL1 and PtVDL2 inserted to $\mathrm{pET}-15 \mathrm{~b}$ cloning region were compared with sequences of these genes of the $\mathrm{Ph}$. tricornutum CCAP 1055/1 strain (Accession numbers (NCBI): XM_002178607, XM_002180599, XM_002180015, respectively) using BLASTT and ExPASy. Plasmids were sequenced by Genomed (Poland). PET-15b/PtVDE, and pET-15b/PtVDL2 plasmids (similar sequences to the respective $P h$. tricornutum gene) were used to transform E. coli Origami b (DE3) (Novagen) and BL21(Novagen) cells. To $200 \mu \mathrm{l}$ of competent cells $20 \mathrm{ng}$ of respective pET-15b vector was added, mixed gently, and incubated for $30 \mathrm{~min}$ on ice. Transformation mixtures were transferred to a $42^{\circ} \mathrm{C}$ water bath and incubated exactly $90 \mathrm{~s}$ followed by $2 \mathrm{~min}$ on ice. Transformed cells were added to pre-heated $\left(37^{\circ} \mathrm{C}\right) \mathrm{LB}$ and incubated for $1 \mathrm{~h}$ at $37^{\circ} \mathrm{C}$. The bacteria from the transformation mix were spread on selective LB (Ampicillin 100) agar plates (modified method of Swords, 2003).

Electrophoresis and immunoblotting. Transformed E. coli cells after induction of protein overexpression by IPTG $(0.5 \mathrm{mM})$ grown for $20 \mathrm{~h}$ at $22^{\circ} \mathrm{C}$ were collected incubation with an alkaline phosphatase-conjugated antimouse secondary goat antibody (Sigma), and visualized by the BCIP/NBT liquid substrate (Sigma).

Violaxanthin de-epoxidation activity. E. coli cells were collected, centrifugated and sonicated. The enzyme activity was measured with violaxanthin as a substrate $(0.33 \mu \mathrm{M})$, in the presence of monogalactosyldiacylglycerol (MGDG) $(9 \mu \mathrm{M})$ and $100 \mu \mathrm{l}$ of sonicated cells in $0.1 \mathrm{M}$ citric buffer $(5.1 \mathrm{pH})$ were used as a source of the de-epoxidase. The reaction was initiated by the addition of ascorbate to a final concentration of $30 \mathrm{mM}$ and this was carried out at room temperature. Samples were collected at $0,5,10$ and $30 \mathrm{~min}$ of reaction. De-epoxydation was stopped by mixing $700 \mathrm{ml}$ of assay mixture with $50 \mathrm{ml}$ of $1 \mathrm{M} \mathrm{KOH}$ (Yamamoto, 1985). The level of xanthophyll pigments (violaxanthin as a substrate, antheraxanthin and zeaxanthin as products) was analyzed by reverse phase HPLC chromatography (Latowski et al., 2002).

\section{RESULTS AND DISCUSSION}

The determination of the complete DNA sequence of $\mathrm{Ph}$. tricornutum has provided a new opportunity for the gene expression analysis of diatoms, which are important component of marine phytoplankton, and which play an important role in global carbon cycling (diatoms fix more carbon then the most productive terrestrial ecosystem, the tropical rainforests) as well as in the regulation of the biogeochemical cycle of silicon in the ocean (Smetacek, 1985; Egge \& Aksnes, 1992; Treguer et al., 1995; Dugdale \& Wilkerson, 1998; Geider et al., 2001; Yool \& Tyrrell, 2003). The methodology for reverse ge-

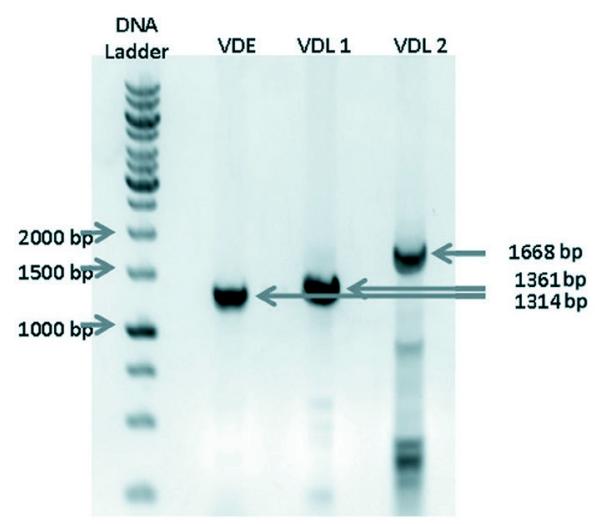

Figure 1. PCR amplification of PtVDE, PtVDL1 and PtVDL2.

CDNA used as a template was obtained by reverse-transcription of mRNA isolated from a 5 day old batch culture of Ph. tricornutum UTEX 645 . The products were separated in $1 \%$ agarose gel and then visualized with ethidium bromide. 
A

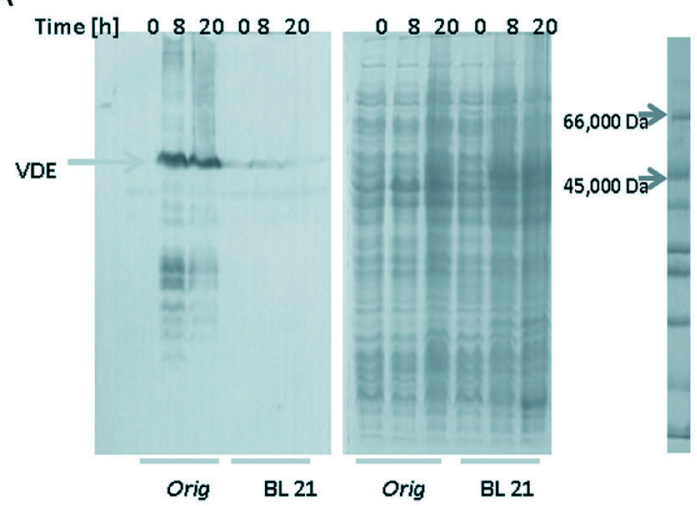

B

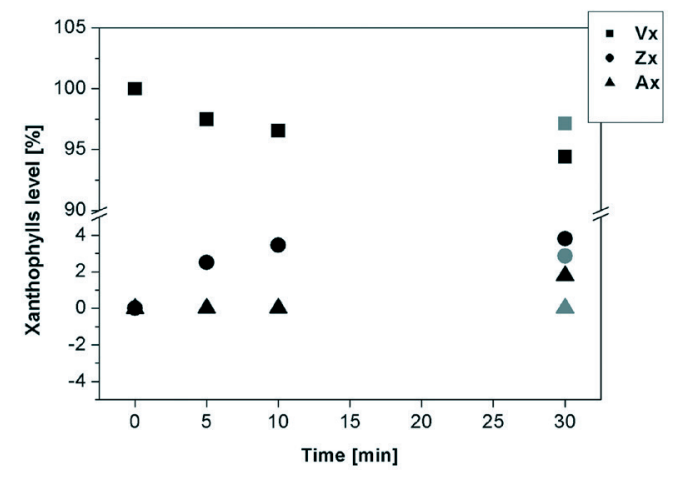

Figure 2. (A) SDS/PAGE electrophoresis gel (on the right) and western blot detection (on the left) of VDE after IPTG induction $\left(0,8\right.$ and $20 \mathrm{~h}$ at $22^{\circ} \mathrm{C}$ ), in Origami $b$ and BL21 cell extracts. (B) The kinetics of violaxanthin de-epoxidation (samples collected at $0,5,10,30 \mathrm{~min}$ ) catalyzed by overexpressed VDE present in bacteria cells extract: Origami $b$ (gray) and BL21 (black). Vx violaxanthin, $\mathrm{Zx}$ - zeaxanthin, Ax - anteraxanthin.

netics allows to the expression of cloned genes in heterologous systems in order to identify the function of the protein encoded (Siaut et al., 2007). The typical methodology was applied to the expression of three genes of $P h$. tricornutum de-epoxidase, and to test the enzymatic activity of the mature proteins.

During the first stage, three PCR products with bp values corresponding to PtVDE, PtVDL1 and PtVDL2 of Ph. tricornutum CCAP 1055/1 were obtained (Fig. 1)

PtVDE, PtVDL1 and PtVDL2 were inserted to pet $15 \mathrm{~b}$ vector cloning region and sequenced. The comparative analysis of both strains of $P h$. tricornutum VDE-genes shows that PtVDE and PtVDL2 had highly identical $(99 \%)$ nucleotide sequences in diatom strains tested. Translation tool of the obtained PtVDE and PtVDL2 DNA sequences in to protein sequences and their comparison with the protein sequences of PtVDE and PtVDL2 of Ph. tricornutum CCAP 1055/1 strain show differences in two positions. The amino acids of PAVDE of Ph. tricornutum UTEX 645 identified as differing from PtVDE of $\mathrm{Ph}$. tricornutum CCAP 1055 /1 were localized in the N-terminal targeting sequence (Ser $\rightarrow$ Leu 13) and in the Glu-rich domain (Leu $\rightarrow$ Val 413). VDL2 of UTEX strain was different from VDL2 of CCAP in two sites located in the Cys-rich domain (Leu $\rightarrow$ Met 107) and in the lipocalin domain (Lys $\rightarrow$ Glu 378 ).

The de-epoxidase genes obtained (PtVDE and PtVDL2), showed a different expression level dependent on the time of induction and E. coli strains. The presence of VDE and VDL2 proteins after IPTG induction
A

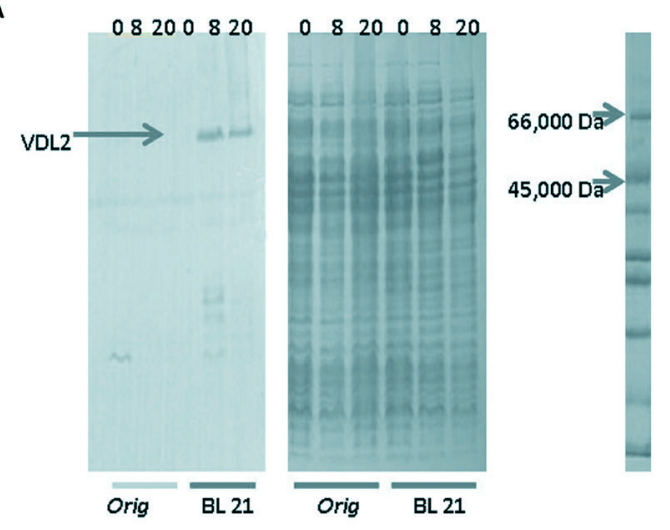

B

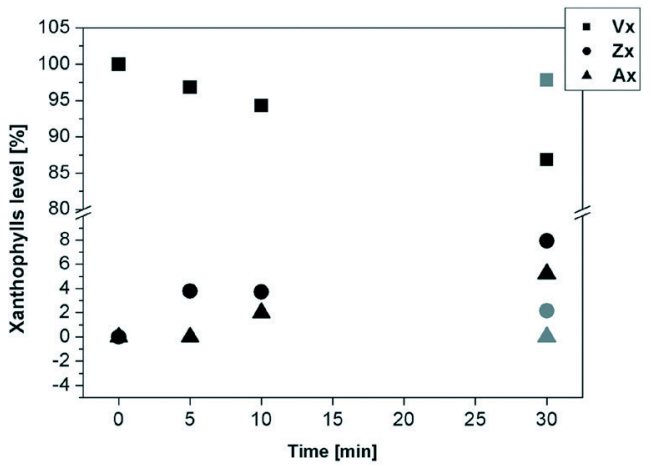

Figure 3. (A) SDS/PAGE electrophoresis gel (on the right) and western blot detection (on the left) of VDL2 after IPTG induction $\left(0,8\right.$ and $20 \mathrm{~h}$ at $22^{\circ} \mathrm{C}$ ), in Origami $b$ and BL21 cell extracts. (B) The kinetics of violaxanthin de-epoxidation (samples collected at $0,5,10,30 \mathrm{~min}$ ) catalyzed by overexpressed VDL2 present in bacteria cells extract: BL21 (black) and Origami $b$ (gray). Vx violaxanthin, $\mathbf{Z x}$ - zeaxanthin, Ax - anteraxanthin.

(8 and $20 \mathrm{~h}$ ) were visualized on SDS/PAGE electrophoresis as a dark band up to the $45 \mathrm{kDa}$ and close to the $65 \mathrm{kDa}$ marker level (for VDE $49 \mathrm{kDa}$ and VDL2 60 $\mathrm{kDa}$, respectively). Western-blot analysis with His-tag antibodies confirmed proteins expression (Fig. 2A and $3 \mathrm{~A})$. The stable expression of the genes obtained were observed in Origami b for PtVDE and in BL21 for PtVDL2 (dark bands), whereas in BL21 and in Origami $b$ lower expression was observed for PtVDE and PtVDL2, respectively.

The activity of mature recombinant VDE and VDL2 after $20 \mathrm{~h}$ induction by IPTG was also observed. The results show that both enzymes expressed in Origami $b$ and BL21 E. coli strain catalyzed violaxantin deepoxidation. The dynamics between conversion of $\mathrm{Vx}$ into $\mathrm{Ax}$ and $\mathrm{Zx}$ depended on the enzyme expression level. VDE inducted in Origami $b$ strain converts about $4 \% \mathrm{Vx}$ to $\mathrm{Zx}$ as the final product reaction whereas VDE inducted in BL21 only 3\% after 30 min running of the reaction. Under the same experimental conditions VDL2 induced in BL21 converted $8 \% \mathrm{Vx}$, whereas VDL2 induced in Origami $b$ strain converted 2\% Vx (Fig. $2 \mathrm{~B}$ and $3 \mathrm{~B}$ ) only.

These results show the effective expression of two of the three $P$ h. tricornutum active de-epoxidases.

\section{REFERENCES}

Coesel S, Obornik M, Varela J, Falciatore A, Bowler Ch (2008) Evolutionary Origins and function of the carotenoid biosynthetic pathway in marine diatoms. PLoS ONE 3: e2896 1-16. 
Dugdale RC, Wilkerson FP, (1998). Silicate regulation of new production in the equatorial Pacific upwelling. Nature 391: 270-273.

Egge JK, Aksnes DL, (1992). Silicate as regulating nutrient in phytoplankton competition. Mar Ecol Prog Ser 83: 281-289.

Geider RJ, Delucia EH, Falkowski PG, et al. (2001) Primary productivity of planet earth: biological determinants and physical constraints in terrestrial and aquatic habitats. Global Change Biol 7: 849-882.

Goss R, Jakob T, (2010) Regulation and function of xantophyll cycle-dependent photoprotection in algae. Photosynth Res 106: 103-122.

Guillard RRL, Ryther JH, (1962) Studies of marine planktonic diatoms: I. Cyclotella nana Hustedt and Detonula confervacea (Cleve) Gran. Can J Microbio 8: 229-239.

Guillard RRL, (1975) Culture of phytoplankton for feeding marine invertebrates. In Culture of Marine Invertebrate Animals, Smith WL, Chanley MH eds, pp 26-60. Plenum Press, New York, USA.

Jahns P, Latowski D, Strzałka K, (2009) Mechanism and regulation of violaxanthin cycle: The role of antenna proteins and membrane lipids. Biochim Biophys Acta 1787: 3-14.

Latowski D, Kruk J, Burda K, Skrzynecka-Jaskier M, Kostecka Gugała A, Strzałka K (2002) Kinetics of violaxanthin de-epoxydase by violaxanthin de-epoxydase, a xantophyll cycle enzyme, is regulated by membrane fluidity in model lipid bilayers. Eur J Biochem 269: 4656-4665

Siaut M, Heijde M, Mangogna M, Montsant A, Coesel S, Allen A, Monfredonia A, Falciatore A, Bowler C (2007) Molecular toolbox for studying diatom biology in Pheodactylum tricornutum. Geen 406: 23-35.

Smetacek VS (1985) Role of sinking in diatom life-history cycles: Ecological, evolutionary and geological significance. Mar Biol. 84: 239251.

Swords WS (2003) Chemical transformation of E. coli. In Methods in Molecular Biology. E. coli palasmid vectors. Casali N, Preston A eds, vol 234, pp 49-53. Humana Press Inc. Totowa NJ.

Treguer P, Nelson DM, Van Bennekom AJ, DeMaster DJ, Leynaert A, Queguiner B (1995) The silica balance in the world ocean: A reestimate. Science 268: 375-379.

Yamamoto HY, (1985) Xantophyll cycle. Methods Ensymol 110: 303-312.

Yool A, Tyrrell T, (2003). Role of diatoms in regulating the ocean's silicon cycle. Global Biogeochemical Cycles 17: 1103-1124. 